\title{
Research paper on Case laws of Fraud, forgery and Corruption in Banks and Financial Institutions in India
}

\author{
Hari Ram Anthala, \\ M.A.(Pol.Sc.) , LL.M, (NET) CAIIB, (Ph.D) \\ Advocate\& Legal Consultant. Punjab \& Haryana High Court, Chandigarh,Distt.\& Session Courts, Ambala \\ (Haryana) \\ Assistant Professor of Law, Delhi Institute of Rural Development, Holambi Khurd-Delhi \\ (Affiliated to SGSIP University, New Delhi) \\ Research Scholar (Ph.D), Deptt of Laws, P.U. Chandigarh \\ H.No.2033/lVishwakarma Nagar, Baldev Nagar, Ambala City -134007 (Haryana) \\ Emai; hranthala@gmail.com hrnthala@ rediffmail.com M 9416976551,8744036978
}

\begin{abstract}
Corruption in civilized society is disease like cancer which is not detected in time is sure to spread its malignance among the polity of the country leading to disastrous consequences. Corruption is opposite to democracy and social order and being of only anti-people but also due to fact that it effects the economy of a country and destroy its cultural heritage. It poses threat to the concept of constitutional governance and shakes the very foundation of democracy and rule of law. The purpose of this study is get rid from fraud and corruption committed by the criminals, outsiders customers and employees of the banks and financial institutions and other State, Central and Local bodies, public and private sectors. The detection of fraud and corruption has become a big problem. This phenomenon surprisingly is not limited to a particular area, city, or country. It is throughout the world. The word fraud is defined under Sec. 17 of the Indian Contract Act, 1872 and Forgery is defined under Sec.163 of the Indian Penal Code, 1860. The main objectives of this research paper are as
\end{abstract} under:

- To study the information's of law relating to fraud and corruption in banks and financial institutions is essential.

- $\quad$ To examine the nature of evil of fraud and corruption in the banks and financial institutions which is increasing in spite of implementation of various law?

- $\quad$ To study dimensions of fraud and corruption in earlier and modern time.

- $\quad$ To identify and examine the role played by the C.B.I., Central Vigilance Commission, Police and other agencies with regard to fraud and corruption in the banks and financial institutions.

- To study the law and policies in India for prevention of fraud and corruption in Banks and financial institutions.

- $\quad$ To study the need to strengthen and harmonize the law and policies regarding fraud and corruption in banks and financial institutions while ensuring its compliance with international law.

The fraud, forgery and corruption is commonly found in exchange of services rely on Information and Technology and the absence of physical bank branches to provide these services to the customers. There is great increase in E-banking and M-banking. The virtual banking becomes very popular amongst the customers due to speed, convenience and round-the-clock access. The Information Technology Act, 2000 has been passed by the parliament which gives recognition to the transitions undertaken through computer system and internet. Frauds and corruption are on increase. Some of the reasons are: speedily expansions of foreign and private banks i.e., increase of number of branches, increase in volume of business, increase inn number of employees, number of customers and spread of operations. These are the contributing factors to the higher incidence of banks frauds and forgeries.

Key Words: Fraud, corruption, forgery, Consumer Protection Act, CBI, CVC, Police, Banking \&financial institutions,

An effort has been made to highlight below the three decided cases in which fraud and corruption is involved in the banks and financial institutions with facts:

(1) N.V. Subarao v. State of Andhra Pradesh: Administrative Action, Role of CBI, Supreme Court, Constitutional Law.

(2) Gurgaon Gramin Bank v.Khazani: Harassment to the gramin borrower by the bank, Role of Distt. Consumer Forum, State Commission/ National

(3) M/s Piara Singh Cold Storage v. Canara Bank and Anothers: Commission Misuse of Loan by the borrowers, Dishonour of Cheques, Debt Recovery Tribunal. 


\section{I. $\quad$ N.V. Subarao v. State of Andhra Pradesh ${ }^{1}$}

Facts of the case are as under:

That a case was registered against Sh.V.N.Subarao, the then Manager, Central Bank of India and Sh. Attur Prabhakar Hegde, Prop of M/s A.P.Enterprises, Guntur for commission of Offence ${ }^{2}$ alleging that Manager has abused his official position as a public servant and entered into a criminal conspiracy with Prop And defrauded the Bank to the tune of Rs.1.168 crores by sanctioning temporary overdrafts and term loans to various individual sponsored by the said proprietor. A charge sheet was filed by CBI. The Manager fraudulently and dishonestly disbursed 494 loans of Rs.10000 each to various railway employees and other organization as he was instructed by his controlling officers to disburse loans only after obtaining undertaking from their employers (borrowers) that the monthly installment of repayment of loan will be deducted from the salaries as primary security and also obtain a mortgage on the plots sold to the borrower through the Prop M/s.A.P.Enterprises. An amounting to Rs.49, 40,000 and credited the proceeds to the account of the Proprietor without obtaining the requisite undertaking from the employers and without proper security of monthly installments to be deducted from their salaries. Out of 494 borrowers, 45 persons have been identified by the prosecution M/s. A.P. Enterprises after having received the proceeds fraudulently and dishonestly did not got 45 plot registered in their names nor the borrowers got the loan amount from the bank.

The Special Judge for CBI cases, Vishakhapatnam sentenced them for 1 year rigorous imprisonment ${ }^{3}$ and to undergo RI for a period of two years along with a fine of Rs.5000, in default, to further undergo imprisonment for 3 months in lieu of offences punishable ${ }^{4}$. Manager was further sentenced undergo RI for 1 year along with fine of Rs.200, in default, to further undergo simple imprisonment for 2 months for the offences punishable ${ }^{5}$ and also ordered that sentences shall run concurrently.

N.V. Subarao v. State of Andhra Pradesh ${ }^{6}$ Two appeals were filed before the High Court of Andhra Pradesh at Hyderabad. The appeals were dismissed and confirmed the conviction and reduced the sentence of Two years to one year and preferred these appeals by ways of special leave and leave was granted on 20.10.08.

There was wrongful loss to the Bank as well as to the purchasers. No mortgage was created putting loss to bank of Rs. 4, 50,000. M/s A.P.Enterprises provided FCNR deposits to the Bank to the tune of Rs.8 crores for a period of 3 years. However the Prop has purchased 60 acres land at Gorantla village near Guntur and 463 plots were registered. The Manager forwarded the proposal of M/s A.P.Enterprises to Regional Office, Vijawadda for sanction of Overdraft facility of Rs.12 lac and sanctioning terms loan to borrowers for purchase of plot from M/s A.P. Enterprises on the basis of FCNR deposits.

It was also stated by Bank Manager that for total of 957 borrowers, only 122 letters of undertaking had been obtained. Pre inspection of the borrowers \& plot was not conducted as per the Manual of Instructions of the Bank Hence Administrative action. The Manager could not delegate responsibility to someone else thus Debt, Financial and Monetary laws provide Misconduct N.V. Subarao v. State of Andhra Pradesh ${ }^{7}$ and. Non delegable duties ${ }^{8}$. No Bank account was opened for theloanees. Bank Manager caused monetary loss to Bank on the presumption ${ }^{9}$ without following established procedure ${ }^{10}$ and debt, financial and monetary law- Bank Scam/Criminal conspiracy/ embezzlement/ forgery ${ }^{11}$.

Preponderance of probabilities-Prosecution established its charges beyond reasonable doubt ${ }^{12}$ by adducing acceptable evidence ${ }^{13}$. Criminal conspiracy was held and proved ${ }^{14}$ and acceptance of money from and transfer

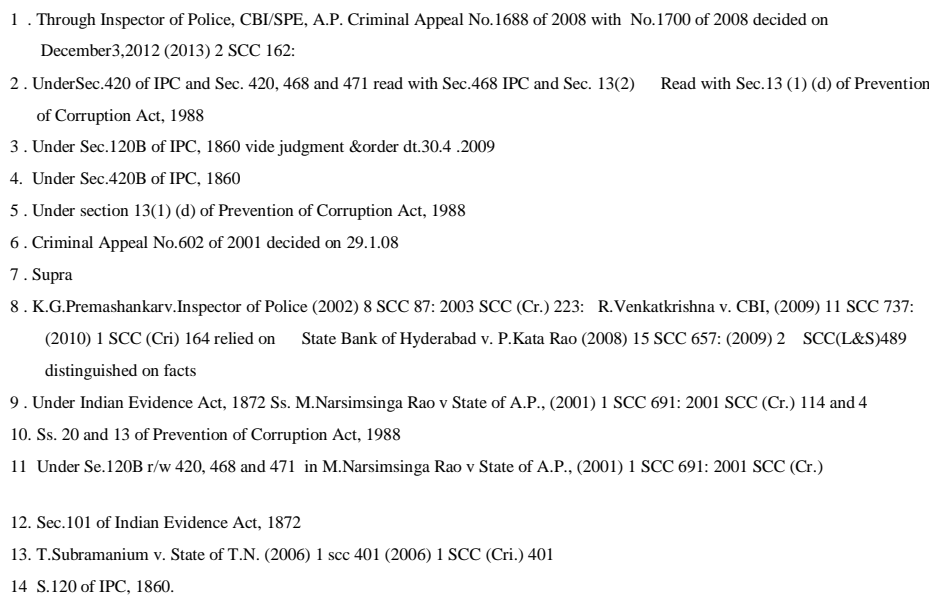


of fraudulently sanctioned loans to credit of the account and hence conspiracy established and debt, financial and monetary law.

\section{Bank Scam/Criminal conspiracy/embezzlement/forgery}

However the several decrees obtained. And few mortgages created but in K.G.Premshanker v. Inspector of Police $^{15}$ and R.Venkatkrishnanv.C.B. ${ }^{16}$.

Departmental Enquiry was conducted against the Bank Manager and accordingly he was dismissed from the services however the attention of the Court was drawn to a decision in State Bank of Hyderabadv.P.Kota Rao ${ }^{17}$ and State of M.P.v.SheetlaSahai ${ }^{18}$ but was not helpful and court held that offence of criminal conspiracy can also be proved by circumstantial evidence. It was contended that orders be set aside on the basis of decisions including in KashinathMondal v. State of West Bengal. ${ }^{19}$

It was held that in view of the concurrent findings recorded by both the courts based on acceptable evidence in the form of oral and documentary evidence, we are of the opinion that it is not a fit case where we should exercise discretionary jurisdiction ${ }^{20}$, consequently both the appeals fail and are accordingly dismissed.

\section{Gurgaon Gramin Bank v.Khazani ${ }^{21}$}

Harassment to the gramin borrower by the bank- Role of Distt. Consumer Forum, State Commission/ National Commission Consumer Protection Act,1986.\& Supreme Court,

Facts of the case are as under:

That Smt. Khazani availed buffalo loan from appellant bank and was insured for Rs.15000/- for period from 6,2,01 to 6.2.04 vide animal tag NIA/03170 WITH New India Assurance Com Ltd 2nd respondents and premium was paid Rs.759/- vide receipt No.170612 dt, 5.0.01. The buffalo was unfortunately died on 27.12.01. She lodged claim for insurance money through bank and supplied them ear tag. No step was taken by the Bank or Insurance Company. She served notice dated 30.07 .03 but yielded no result.

She filed complaint bearing No.824 before the District Consumer Dispute Redressal Forum ${ }^{22}$ the same was allowed vide order dated 26.07.07 with the direction to Insurance Company to pay money of buffalo together with rate of interest @ 9\% p.a. from the date of death of buffalo and pay Rs.3000/- as cost of litigation and compensation for harassment to comply within one month.

The Bank was dissatisfied and filed an appeal before the State Commission ${ }^{23}$, Haryana, Panchkula , Admittedly tag No 03170 and post mortem report.

The Bank and Insurance Company denied. Field Officer reported that when the buffalo died there was no tag and tag was not sent to opposite party.

Bank moved to National Commission ${ }^{24} \mathrm{New}$ Delhi against the order dated 21.07 .09 of State Commission. The National Commission found no error/ irregularity inn exercise of jurisdiction and ordered accordingly on 25.11 .09

SLP against the order dated. 25.11.09 was filed and Khazani was brought to Supreme Court. May be ill luck of Bank, Bank is caused to worked, how much amount spent till date on this dispute which relate to death of buffalo stake of which is Rs.15000/- and bank will file an affidavit within 4 weeks with regard to amount spent on litigation. The Chief Manager of bank filed an affidavit for expenditure as under:

Amount spent by Bank: District Forum Rs.2400 State Commission 2650 and Supreme Court 8500/- total Rs. 12950 The Supreme Court has not been told by the bank how much money have been spent by Bank officer for their to and fro journey to lawyers office, the District Forum, State Commission, National Commission and Supreme Court for partly amount o Rs.15000/-. As per affidavit bank spent Rs. 12950/- . District forum awarded Rs. 3000/- towards cost of litigation and compensation for harassment caused to Khazani.

\section{The Supreme Court remarked as under:}

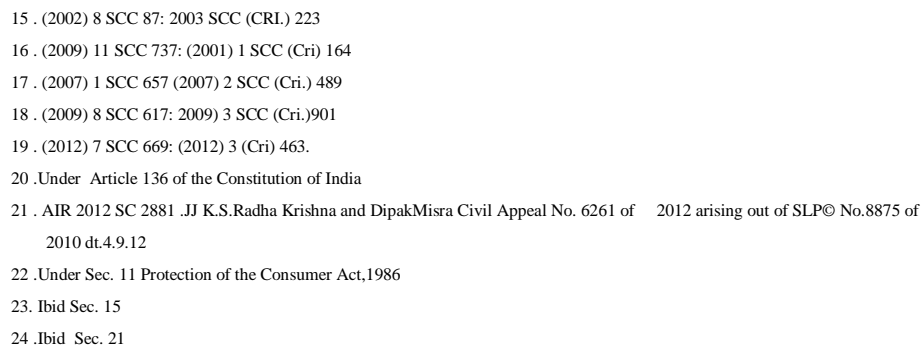


Remember buffalo died 10 years back till litigation is not over.

Advocate argued that claim was false as no tag was found on dead buffalo.

These types of litigation should be discouraged and message should also go otherwise for all trivial matters. People will rush to this court.

Gramin Bank like appellant should stand for benefit of grant- Repayment to large extent depends more they get.

Driving poor gamins to various FORUMS should be strongly depreciated because they have to spent large amount for conduct of litigation. We condemn these types of practice unless the stake is very high or matter affects a large number of persons or effects a general policy of the Bank which has for reaching consequence.

Appeal is dismissed with cost of Rs.10000/- to be paid by bank to first respondent within a period of one month resultantly bank has to spend Rs. 25930/ for claim of Rs. 15000/- spent to and fro traveling of the Bank officer. Let God save the Gramin.

\title{
III. M/s Piara Singh Cold Storage v. Canara Bank and Anothers ${ }^{25}$
}

\author{
Misuse of Loan by the borrowers, Dishonour of Cheques, Debt Recovery Tribunal, Constitutional Law. \\ The facts of the case as under:
}

That M/s Piara Singh Cold Storage was granted an agricultural loan of Rs.25 lakhs for modernization of cold storage, for which rate of interest was less than the commercial use of loan for commercial purpose. The debtor was in breach of terms and conditions of the agriculture loan as the cold storage was converted into marriage palace. The term loan was granted on 30.3.2000 to be repaid within seven years against mortgage of 18 Kanal of land Village Rehan Jattan, Phagwara Distt. Kapurthala. He repaid Rs. 6 lac up to 7.4.01. The respondent Bank started proceeding under D.R.T ${ }^{26}$ and proceeding were initiated due to dishonor of cheques ${ }^{27}$. He applied for one time settlement of Agriculture loan.

The main dispute was that borrower was granted agriculture term loan but the petitioner stated that there was downfall in market and cold storage was not running in profit. He had filed no application for diversion of funds.

It was held that petitioner is guilty of breach of terms and conditions of the agriculture term loan. Therefore, he cannot ask for one time settlement and should not be permitted for equitable relief. The petitioner is devoid of any merit and is frivolous and deserves to be dismissed out rightly ${ }^{28}$.

Accordingly petition is dismissed with cost of Rs.5000/- which shall be paid by petitioner to High Court Legal Services Committee within 15 days.

\section{Conclusions:}

On going through the discussions in all the three decided that how the public and Banks and financial institutions employees and outsiders are playing their vital roles in fraud, forgery and corruption in the banking and financial institutions. This tendency must not occur in the banking and financial institutions. However, law is there but implementation is poor. The Public Interest Litigation PIL has proved to be a strong and potent weapon in the hand of Court enabling it to unearth many scams and corruption cases in public life and to punish guilty involved in those Scam. Hawala Scam, Urea Scam, Fodder Scam in Bihar, St.Kit Scam, Ayurvedic Medicine Scam and illegal Allotment of Government Houses and Petrol Pumps has come to light through Public Interest Litigation. The detection of fraud and corruption has become a big problem. This phenomenon surprisingly is not limited to a particular area, city, or country. It is throughout the world. There must be strict law and severe punishment must be there to curb the fraud, forgery and corruption. The judiciary has also played its role through various judgments delivered by the Supreme Court of India, High Courts and District Consumer Redressal Forum, State Consumer Redressal Forum and National Consumer Redressal Commission. Thus analysis on the scrutiny of fraud and forgery and corruption provisions, judicial functioning and to create new provisions for arresting fraud, forgery and corruption in banks and financial institutions. The criminal persons who commit fraud, forgery and corruption in the banks and financial institutions must be given life imprisonment and sent behind the bar so that coming generation my not commit any fraud and forgery which case huge loss to the government revenue and cause great problems to Banks, Financial Institution because after committing fraud and corruption the role of police department, Central Bureau of Investigation, Central Vigilance Commission started as per the quantum of fraud and forgery. The scope of the Disciplinary action

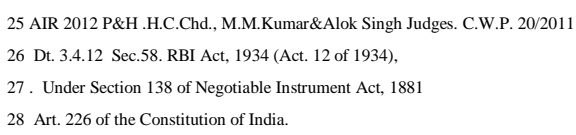


under administrative law has been very vast during the tenure of the services of the employees in the concerned departments. While discharging their duties with sincerity, dedication and devotion, sometimes something wrong may be committed under pressure, coercion and threat, but one should not come under any undue influence and work as per rules, regulations and laws enacted for checking menace of fraud and forgery in the banks. The C.V.C has also played its role and establishment of vigilance Department in all the banks at Head Offices and Regional as well as Zonal Offices in the country for checking the menace of fraud and forgery in the banks. The Reserve Bank of India has also been issuing directions got prevention of fraud and forgery in all the banks and reporting system to Higher Authorities, including C. B. I, C.V.C. and State Police. The judiciary has also played its role through various judgments delivered by the Supreme Court of India, High Courts and District Consumer Redressal Forum, State Consumer Redressal Forum and National Consumer Redressal Commission. Thus analysis on the scrutiny of fraud and forgery and corruption provisions, judicial functioning and to create new provisions for solution of the fraud and corruption in the Banks and financial institutions. 